процесу, невдале поєднання дітей за віком та гендером, недостатній менеджмент з боку адміністрації школи, несправедливість у порівнянні таких учнів з учнями зі звичайних класів. На основі проведеного дослідження було розроблено такі рекомендації для покращення системи мультикласового навчання: ураховуючи обмежений час занять, необхідно переглянути підручники та посібники, які використовуються для навчання у звичайних класах, переробити або адаптувати їх для забезпечення адекватного навчального процесу під час мультикласових занять; необхідно розміщувати учнів на уроці у залежності від їхнього віку та статі - ближче один до одного - для забезпечення взаємодії, наприклад, в одному ряді посадити учнів першого класу, в іншому - третього класу тощо; також рекомендовано забезпечувати тіснішу взаємодію слабких старших студентів із молодшими учнями задля того, щоб вони у взаємодії проходили матеріал; слід залучати відповідальних людей до забезпечення таких шкіл необхідним приладдям для реалізації освітнього процесу; рекомендовано накопичувати та використовувати успішний досвід інших країн у проведенні мультикласових занять.

Ключові слова: виклик, проблеми, мультикласове навчання, вчителі, якісний аналіз.

Подано до редакиіії 25.12.2016

UDC: $372: 37.016-021.4$

\author{
Nassim Shamoradi Varnamkhasti, \\ MA in Curriculum Planning, \\ Isfahan (Khorasgan) Branch, Islamic Azad University, Isfahan, Iran, \\ Maryam Baratali, \\ associate professor, Department of Educational Sciences, \\ Isfahan (Khorasgan) Branch, Islamic Azad University, Isfahan, Iran
}

\title{
RELATIONSHIP BETWEEN SENIOR HIGH SCHOOL TEACHERS' MEDIA AND INFORMATION LITERACY, EMOTIONAL INTELLIGENCE AND TEACHING QUALITY
}

The research aims to investigate the relationship between media and information literacy, emotional intelligence and teaching quality of senior high school teachers. The research was performed by means of the correlation research method. The statistical population of the study included all high school teachers in Zarinshahr region ( $n=460)$. The sample size $(n=130)$ was determined on the basis of Krejcie \& Morgan table (1970) using random multistage cluster sampling method. In order to assess the teaching quality of the surveyed, 3 students per a teacher were selected. Data collection was carried out using the following three scales: Ashrafi-Rizi Media \& Information Literacy Questionnaire (2014), The Modified Teaching Quality Scale developed by Safdarian (2015) and Khosrowpour (2015) as well as Schutte Self-Report Emotional Intelligence Test (1998). Using Cronbach's alpha, the reliability of the three used scales were found to be 0.925, 0.925 and 0.924, respectively. In addition, data were analyzed by applying SPSS 22 and AMOS 23 software in two levels of descriptive and inferential statistics with Pearson's correlation coefficient tests, simultaneous regression, one-way analysis of variance (ANOVA) test and two independent groups T-test as well as structural equation modeling. As per the results of the study, there was a paired direct and statistically significant relationship between media and information literacy, emotional intelligence variables and teaching quality variable $(P \leq 0.01)$. The structural equation model obtained from the quantitative, predictor and criterion variables indicated that the three variables in question including information literacy and emotional intelligence could explain $34.6 \%$ of the variance obtained for the teaching quality variable which can be considered as a very good explanation percentage revealing the acceptable fitness of the model with the study data. Furthermore, it has been found that the difference between the mean scores obtained for the main variables of the study (i.e. emotional intelligence, media and information literacy and teaching quality) in terms of the demographic characteristics (including gender, field of study, level of education and teaching experience) is not statistically significant.

Keywords: media and information literacy, teaching quality, teachers, high school, emotional intelligence.

\section{Introduction}

In the modern complex world, education plays an increasingly critical role. Due to the rapid development of all the nations and communities in the present time, the significance of the role of education has become evident more than ever. It is obvious that a teacher is considered to be the most active member of the educational process so that paying due attention to the teaching quality would certainly improve the educational system. Along with its current quantitative progress, teachers, as the most significant influential factor, are capable of improving the educational system qualitatively. Nowadays, the quality of education has become an extremely significant issue like other fields including industry and health. This can be justified by the fact that the efficiency of the educational system provides the basis for the socie- 
ty performance. Accordingly, improving the educational system quality is regarded as one of the main indicators involved in the improvement of educational institutions (Hajipour, 2008).

Teaching quality is similarly considered as one of the significant factors in the learning process which is mainly involved in the activities performed by teachers. Educational institutions apply different methods to determine the main attributes of a good teacher. In the modern world, the necessity of paying attention to the teaching quality and its resultant productivity is of particular importance.

Teaching process has a very complicated nature with various components which must be appropriately adopted and developed in order to achieve a high teaching quality. On the other hand, there are numerous factors influencing the teaching process that must be taken into account in terms of achieving high quality teaching. The identification of the effective teaching quality parameters is important due to their critical role in the promotion of the education quality (Nami et al, 2014). One of the parameters which seem to affect the ability of the teachers in providing effective training is their media and information literacy as well as emotional intelligence. In scientific literature in the field, some works are dedicated to the role of these factors in relation to the quality of teaching, fox example, the works of Nami et al (2015), Nasiri (2013), Fallahi \& Rostami (2012), Xu \& Chen, 2016 and Miyagamwala, 2015.

Considering the abovementioned, the present research aims to determine the teaching quality of high school teachers in terms of two variables: media and information literacy and emotional intelligence.

\section{Teaching Quality}

Teaching quality and performance efficiency of every teacher depend on his/her technical competence or expertise in the subject matter of the teaching, job skills as well as personal competence. Incompetency in each of these fields will negatively affect the students' knowledge. The main responsibility of every professional teacher is to facilitate the students' learning. Investment by both a student and a teacher in collaboration-based effort through cooperation will contribute to the improvement of the educational process. The role of a teacher is a very challenging which requires lifelong commitment and desire to learn (Miller \& Miller, 2008). Fenstermacher \& Richardson (2005) argue that efficient teaching is one that leads to learning.

\section{Media Literacy}

According to the definition of the Communications field experts, "media literacy is the ability to access, analyze, evaluate and create messages across a variety of contexts (Christ \& Potter, 1998). A person equipped with this skill can critically think about whatever he/she watches, reads and hears via the books, newspapers, TV and radio, films, music, advertisements, video games and Internet (Sepasgozar, 2001). Media literacy is a multiple capability allowing individuals to receive media messag- es, interpret them critically and express their own thoughts and beliefs (Shibata, 2003).

\section{Information Literacy}

UNESCO has accepted the information literacy as one of the basic human rights necessary for the national development, citizenship and economic welfare as well as a prerequisite for the satisfaction of educational standards. Information literacy highlights the significance of data accessibility, appraisal and usage. In 1999, UK's Society of College, National and University Libraries (SCONUL) presented a model composed of 7 main pillars delineating the concept of information literacy. These components are as follows: 1) being able to identify a personal information need, 2) being able to identify the available data access tools, 3) being able to define search strategies for finding the best available resources, 4) having skills in data search and retrieval including familiarity with advanced search tools, 5) knowledge about the ways of evaluating and comparing the available information resources, 6) skills in using the new collected data and relating them with the acquired knowledge, 7) being able to keep up to date with new information and making contributions for producing new information. The last component is in fact one of the main objectives of higher education (in Mansurian \& Naeimabadi, 2005).

\section{Methodology}

The research was conducted using correlation research method since it aimed to explore the association between media and information literacy, emotional intelligence and teaching quality of high school teachers in the region of Zarinshahr, Isfahan, Iran. Research population consisted of all teachers of senior high schools under the charge of Zarinshahr Education Organization who worked in 2015-2016 academic year $(n=460)$. However, for collecting more realistic data on the teaching quality variable, students' judgments were used instead of teachers' self-assessing and self-reporting. Thus, three students per a teacher were selected to score the teaching quality of their teachers.

To determine the size of the sample taken from the teachers' research population, Krejcie \& Morgan table (1970) was used. In this way, the size of the sample was estimated to be 130. To select the schools, multi-stage stratified sampling method was used. Applying this method, 4 regions were randomly selected which were as follows: Zarinshahr, Fooladshahr, Sede and Varnamkhast. To distribute the questionnaires among the teachers, the selected high schools were visited in person. As it was mentioned earlier, three students per a teacher were also selected to fill in the Teaching Quality Questionnaire. In this research, the following three questionnaires were used in the experiment:

Media and Information Literacy Questionnaire. Developed by Ashrafi Rizi et al. (2015), this questionnaire was used to assess the teachers' level of media and information literacy using self-report method. It has been developed on the basis of the UNESCO media and information literacy definition as well as valid scientific 
resources. It consists of 36 questions, the responds to which are based on 5-point Likert scale with the following arrangement: score $5=$ very high, score $4=$ high, score 3 = average, score $2=$ low, score $1=$ very low. To assess its construct validity, AMOS 23 software was used. According to the obtained results, all the factor loadings were found to be higher than 0.3 . As a result, its construct validity was confirmed revealing that these items have the capability of assessing the media and information literacy appropriately and acceptably.

Teaching Quality Questionnaire. Since there was no standard questionnaire for assessing the teaching quality, a modified questionnaire was derived from Khojastepour (2014) and Safdarian (2014) scales by a revision, modification and balancing of the original items. The final prepared questionnaire was composed of 28 items rated using 5 -point Likert scale $(1=$ very low, 2 = low, $3=$ to some extent, $4=$ high, $5=$ very high) covering 3 distinct dimensions: individual/personality, classroom management and teaching process dimensions.

Schutte Self-Report Emotional Intelligence Test (1998). Covering 33 items, this questionnaire was designed by Schutte et al (1998) based on the initial pattern of emotional intelligence presented by Mayer \& Salovy (1990) for assessing the components of emotional intelligence, i. e. managing self-relevant emotions, emotion expressing and appraising, as well as utilizing emotions.

\section{Findings}

Major hypothesis: there is a multiple association between the media and information literacy, emotional intelligence and teaching quality.

Pearson's correlation coefficients for the main research variables in the sample

Table 1.

\begin{tabular}{|l|l|c|c|c|}
\hline Variable & Coefficient & $\begin{array}{l}\text { Teaching } \\
\text { quality }\end{array}$ & $\begin{array}{l}\text { Emotional } \\
\text { intelligence }\end{array}$ & $\begin{array}{l}\text { Media \& Information } \\
\text { Literacy }\end{array}$ \\
\hline \multirow{2}{*}{ Teaching Quality } & Correlation Coefficient & 1 & $0 / 556^{* *}$ & $0 / 508^{* *}$ \\
\cline { 2 - 5 } & Significance & - & $0 / 000$ & $0 / 000$ \\
\hline \multirow{2}{*}{$\begin{array}{l}\text { Media \& Information } \\
\text { Literacy }\end{array}$} & Correlation Coefficient & - & - & 1 \\
\cline { 2 - 5 } & Significance & - & - & - \\
\hline
\end{tabular}

The items marked with double stars were statistically significant at the confidence level of $99 \%$ so that it can be inferred that teaching quality is significantly and directly related to emotional intelligence with a value of 0.556 that was statistically significant at a level of confidence of $99 \%$. The square of multiple correlation coefficient calculated for teaching quality as the criterion variable in the model was found to be 0.346 indicating that the variables of emotional intelligence and media and information literacy can explain as much as $34.6 \%$ of the variance observed for the criterion variable, i.e. teaching quality which can be regarded as a very good explanation percentage. This result in fact shows that predicator variables placed an effect on the criterion variable and the model fitted the data well.

Minor Hypothesis 1: media and information literacy and its components can predict the teaching quality of the teachers.

Table 2.

Correlation coefficients between media and information literacy, its components and teaching quality

\begin{tabular}{|l|c|c|c|}
\hline \multicolumn{1}{|c|}{ Priterion Variable } & \multicolumn{3}{|c|}{ Teaching Quality } \\
\hline Predia variables & $\begin{array}{l}\text { Correlation } \\
\text { Coefficient }\end{array}$ & $\begin{array}{c}\text { Square of correlation } \\
\text { coefficient }\end{array}$ & $\begin{array}{l}\text { Significance } \\
\text { level }\end{array}$ \\
\hline Medormation Literacy & $0 / 508^{* *}$ & $0 / 258$ & $0 / 000$ \\
\hline 1- Targeted use of media & $0 / 472^{* *}$ & $0 / 223$ & $0 / 000$ \\
\hline 2- Methods of using media & $0 / 304^{* *}$ & $0 / 092$ & $0 / 000$ \\
\hline 3- Information appraisal & $0 / 313^{* *}$ & $0 / 098$ & $0 / 000$ \\
\hline 4- Data mixing & $0 / 493^{* *}$ & $0 / 243$ & $0 / 000$ \\
\hline 5- Data exchange & $0 / 507^{* *}$ & $0 / 257$ & $0 / 000$ \\
\hline 6- Observance of copyright policy & $0 / 336^{* *}$ & $0 / 113$ & $0 / 000$ \\
\hline
\end{tabular}
$\mathrm{P}<0.01 * *$

According to the data rendered in the Table 2, the correlation coefficients obtained for the relationship between media and information literacy and its components and teaching quality were statistically significant.
In detail, there was a statistically significant direct association between the targeted use of media and teaching quality $(\mathrm{r}=0.472)$, methods of using media and teaching quality $(\mathrm{r}=0.304)$, information appraisal and teaching 
quality ( $\mathrm{r}=0.313)$, information composition and teaching quality $(\mathrm{r}=0.493)$, data exchange and teaching quality $(\mathrm{r}=0.507)$ and copyright observance and teaching quality $(\mathrm{r}=0.336)$. Based on the value of determination coefficient $\left(\mathrm{r}^{2}\right)$, it can be inferred that 25.8 of the variance on the media and information literacy and teaching quality variables is in common. Hence, the first hypothesis stating that a statistically significant association exists between media and information literacy and its components and teaching quality was confirmed.

Minor Hypothesis 2: emotional intelligence and its components can predict the teaching quality of the teachers.

Correlation coefficients between emotional intelligence, its components and teaching quality

\begin{tabular}{|l|c|c|l|}
\hline \multicolumn{2}{|c|}{ Criterion Variable } & \multicolumn{3}{|c|}{ Teaching Quality } \\
\hline Predictor variables & $\begin{array}{l}\text { Correlation } \\
\text { Coefficient }\end{array}$ & $\begin{array}{c}\text { Square of correlation } \\
\text { coefficient }\end{array}$ & $\begin{array}{l}\text { Significance } \\
\text { level }\end{array}$ \\
\hline Emotional intelligence & $0 / 556^{* *}$ & $0 / 309$ & $0 / 000$ \\
\hline $1-\quad$ Emotional self-regulation & $0 / 428^{* *}$ & $0 / 183$ & $0 / 000$ \\
\hline $2-\quad$ Emotions appraisal \& expression & $0 / 589^{* *}$ & $0 / 347$ & $0 / 000$ \\
\hline $3-\quad$ Utilizing emotions & $0 / 590^{* *}$ & $0 / 348$ & $0 / 000$ \\
\hline
\end{tabular}

As one can see in the Table 3, the estimated correlation coefficient between emotional intelligence, its components and teaching quality is statistically significant. To put it differently, a direct statistically significant association exists between emotional self-regulation and teaching quality $(\mathrm{r}=0.428)$, emotions expression and appraisal and teaching quality $(r=0.589)$, as well as emotions utilizing and teaching quality $(r=0.590)$. Again, on the basis of the coefficient of determination $\left(\mathrm{r}^{2}\right)$ obtained, $30.9 \%$ of the variance on two variables of emotional intelligence and teaching quality is in common. Accordingly, the second minor hypothesis stating that there is a statistically significant association between the emotional intelligence and its components and teaching quality was confirmed.

Minor Hypothesis 3: there is a statistically significant association between media and information literacy and teaching quality in terms of demographic characteristics including gender, field of study, level of education and teaching experience.

To check this hypothesis, the mean scores obtained for the media and information literacy and emotional intelligence of the teachers in terms of the demographic variable of gender were estimated using independent group T-test, the results of which have been summarized in the Table 4. As it is evident, the level of significance for the variables of media and information literacy and emotional intelligence was higher than 0.05. As a result, it can be concluded that no statistically significant relation exists between the male and female participants so that they have the equal level of media and information literacy and emotional intelligence.

Results of Independent Samples T-Test comparing the male and female teachers in terms of their media and information literacy and emotional intelligence

\begin{tabular}{|c|c|c|c|c|c|c|}
\hline \multirow[t]{2}{*}{ Variable } & & \multicolumn{2}{|c|}{ Levene's test } & \multicolumn{3}{|c|}{$\begin{array}{l}\text { Testing the equality of mean } \\
\text { scores }\end{array}$} \\
\hline & & $\mathbf{F}$ & $\begin{array}{l}\text { Significance } \\
\text { level }\end{array}$ & $\mathbf{t}$ & $\begin{array}{l}\text { Degree } \\
\text { of } \\
\text { freedom }\end{array}$ & $\begin{array}{l}\text { Significan } \\
\text { - } \\
\text { ce level }\end{array}$ \\
\hline \multirow[t]{2}{*}{$\begin{array}{l}\text { Emotional } \\
\text { intelligence }\end{array}$} & $\begin{array}{l}\text { Assuming the equality of } \\
\text { variances }\end{array}$ & \multirow[t]{2}{*}{3.060} & \multirow[t]{2}{*}{0.060} & -0.104 & 127 & 0.917 \\
\hline & $\begin{array}{l}\text { Assuming the equality of } \\
\text { variances }\end{array}$ & & & $-0 / 100$ & $97 / 03$ & $0 / 920$ \\
\hline \multirow{2}{*}{$\begin{array}{l}\text { Media \& } \\
\text { information } \\
\text { literacy }\end{array}$} & $\begin{array}{l}\text { Assuming the equality of } \\
\text { variances }\end{array}$ & \multirow[t]{2}{*}{$0 / 474$} & \multirow[t]{2}{*}{$0 / 492$} & $-0 / 785$ & 127 & $0 / 434$ \\
\hline & $\begin{array}{l}\text { Assuming the non-equality } \\
\text { of variances }\end{array}$ & & & $-0 / 800$ & $121 / 26$ & $0 / 425$ \\
\hline
\end{tabular}

Then the mean scores obtained for the media and information literacy and emotional intelligence of the teachers in terms of the demographic variables of field of study, level of education and teaching experience were estimated using independent group T-test, the results of which are summarized in the Tables 5-7. As per the results given in these tables, all the p-values for the media and information and emotional intelligence variables are greater than 0.05 . 
Hence, it can be concluded that there is no statistically significant difference between these two variables and the viewpoints of the respondents in terms of variables of field of study, level of education and teaching experience so that the mean scores for the variables of the media and information literacy and emotional intelligence variables are equal among the various groups of respondents.

Table 5.

One-way variance analysis of the scores of the respondents for media \& information literacy and emotional intelligence variables considering the demographic variable of their field of study

\begin{tabular}{|l|l|l|l|l|l|l|}
\hline $\begin{array}{l}\text { Main } \\
\text { variables }\end{array}$ & $\begin{array}{l}\text { Between-group } \\
\text { mean square }\end{array}$ & $\begin{array}{l}\text { Between-group } \\
\text { degree of freedom }\end{array}$ & $\begin{array}{l}\text { Between-group } \\
\text { mean square }\end{array}$ & F & $\begin{array}{l}\text { Significance } \\
\text { level }\end{array}$ & Eta \\
\hline $\begin{array}{l}\text { Emotional } \\
\text { intelligence }\end{array}$ & $0 / 277$ & 2 & $0 / 138$ & $0 / 303$ & $0 / 739$ & $0 / 071$ \\
\hline $\begin{array}{l}\text { Media \& } \\
\text { information } \\
\text { literacy }\end{array}$ & $0 / 583$ & 2 & $0 / 292$ & $0 / 666$ & $0 / 516$ & $0 / 113$ \\
\hline
\end{tabular}

Table 6.

One-way variance analysis of the scores of the respondents for the media \& information literacy and emotional intelligence variables considering the demographic variable of their level of study

\begin{tabular}{|l|c|c|l|l|l|l|}
\hline Main variables & $\begin{array}{l}\text { Between- } \\
\text { group mean } \\
\text { square }\end{array}$ & $\begin{array}{l}\text { Between- } \\
\text { group degree of } \\
\text { freedom }\end{array}$ & $\begin{array}{l}\text { Between-group } \\
\text { mean square }\end{array}$ & F & $\begin{array}{l}\text { Significance } \\
\text { level }\end{array}$ & Eta \\
\hline $\begin{array}{l}\text { Emotional } \\
\text { intelligence }\end{array}$ & $2 / 990$ & 3 & $0 / 997$ & $2 / 317$ & $0 / 079$ & $0 / 231$ \\
\hline $\begin{array}{l}\text { Media \& } \\
\text { information } \\
\text { literacy }\end{array}$ & $2 / 918$ & 3 & $0 / 973$ & $2 / 335$ & $0 / 077$ & $0 / 226$ \\
\hline
\end{tabular}

Table 7.

One-way variance analysis of the scores of the respondents for the media \& information literacy and emotional intelligence variables considering the demographic variable of their teaching experience

\begin{tabular}{|l|c|c|l|c|c|c|}
\hline Main variables & $\begin{array}{l}\text { Between- } \\
\text { group mean } \\
\text { square }\end{array}$ & $\begin{array}{l}\text { Between-group } \\
\text { degree of free- } \\
\text { dom }\end{array}$ & $\begin{array}{l}\text { Between- } \\
\text { group } \\
\text { mean square }\end{array}$ & F & $\begin{array}{l}\text { Significance } \\
\text { level }\end{array}$ & Eta \\
\hline $\begin{array}{l}\text { Emotional } \\
\text { intelligence }\end{array}$ & $2 / 990$ & 3 & $0 / 997$ & $2 / 317$ & $0 / 079$ & $0 / 231$ \\
\hline $\begin{array}{l}\text { Media \& } \\
\text { information } \\
\text { literacy }\end{array}$ & $2 / 918$ & 3 & $0 / 973$ & $2 / 335$ & $0 / 077$ & $0 / 226$ \\
\hline
\end{tabular}

\section{Discussion}

The results confirming the existence of a statistically significant correlation between the media and information literacy and teaching quality are in line with the results of a number of other similar studies including Ashrafi Rizi et al. (2015), Nami et al. (2015), Taghizadeh and Kia (2015), Malekipour \& Malekipour (2014), Nasiri (2013), Xu \& Chen (2016), Abdulkareem (2015). At educational organizations, use of the best experiences, benefits and environment by the teachers plays obviously a significant part in satisfying the educational and learning goals of students. Information and communication technologies themselves do not result in promoted teaching quality or developed academic achievements of students, so that applying them in a simple and non-targeted way will waste their time. Here, by acquiring the respective required competence and expertise, the educational authorities can promote not only the students' progress, but also their level of learning. Applying such an approach allows increasing the teachers' skills more quickly by taking the least time for leaning. Therefore, if the teacher becomes proficient in computer knowledge and information literacy, his/her effort made towards the integration of education with computer in the school will be successful. The proficiency the trained teachers have gained over the computer field has paved the way for utilizing the IT. Accordingly, all teachers must acquire the necessary skills in using computers, software applications, databanks and relevant technologies so as to facilitate the lifelong learning process.

Furthermore, the results of this study on the existence of a statistically significant association between the media and information literacy and emotional intelligence correspond with the results of similar studies car- 
ried out by Safdarian Hamedani et al. (2015), Fallahi \& Rostami (2012), Miyagamwala (2015), Jamilya et al. (2014). The occupation of teachers and trainers has allowed them to be strong cultivators of socio-emotional skills of students. Furthermore, it is necessary to encourage teachers (especially more experienced ones) so consider personal, social and emotional skills and enhance them systematically through emotional intelligence. Teachers inherently know that they have a very significant role in the students' scientific future and their success in life. Though teaching is not only a stressful and troublesome job but also it can be very exciting. Teachers should "record" their own feelings and students" emotions on a daily basis to analyze them. Besides, the development and control of emotions can have effect on the behavioral outcomes of students. An increase in the teachers' emotional intelligence can remarkably and significantly promote the students' learning in both the scientific and interpersonal domains. There are special trainings administered for both novice and highly experienced teachers for the development of their emotional intelligence development via education plans. Such plans can be designed by the school's psychologists and advisors that can facilitate their integration within in-service education. As a result, the capability of the teachers in self-regulating and managing their emotions in the classroom is a main factor for the successful and effective teaching. Compared to all other skills possessed by a teacher, the capability for responding to difficult and

\section{REFERENCES}

1. Alabdulkareem, S. A. (2015). Exploring the Use and the Impacts of Social Media on Teaching and Learning Science in Saudi. Procedia - Social and Behavioral Sciences 182, 213-224.

2. Ashrafi Rizi, H., Hasnzadeh, D., Kazempour, Z. (2014). The Level of Media \& Information Literacy among the Students of Isfahan University of Medical University in Terms of UNESCO's Media \& Information Literacy. Health Information Management, 11(4), 424-434.

3. Chan, D. W. (1992). Teachers as Clinicians: Inadequacies in Teacher Education. Education Journal, 20, 37-42.

4. Christ W., Pottter W. J. (1998). Media Literacy: Media Education and Academy. Journal of Communication, 48(1).

5. Fallahi, V., Rostami, K. (2012). Role of Emotinal Inelligence in the Effectiveness of Teachers in the Guidance School. Scientific-Research Quarterly of a New Approach towards Educational Management, 3(1), 167-188.

6. Hajipour, M. (2008). The Necessity and Significance of Management Improvement. Quarterly of Management in Education, (pp. 100-105).

7. Jamilya B. Akhmetovaa, Alla M. Kima, Delwyn L. Harnischb. (2014). Using Mixed Methods to Study Emotional Intelligence and Teaching Competencies in Higher Education. Procedia - Social and Behavioral Sciences 128, 516-521. unexpected situations may be more challenging. When reaction time is short, the teacher must be able to create a rapid emotional adaptability even in extremely negative class situations that are unpredicted and unplanned and require appropriate emotional adaptability.

\section{Conclusions}

According to the research results, media and information literacy and emotional intelligence are significantly related to the teaching quality. Today, the information explosion has emphasized the necessity and importance of media literacy more than ever. In fact, every day huge waves of new knowledge and information are introduced into the market via various media including magazines, newspapers, TV and Internet with a very high speed. Accordingly, if a teacher lacks media literacy, he/she will "get drawn in this sea of information". All media contain messages communicating with the society in this way. However, we should not be just passive receivers of these messages. If we are taught by the teachers who possess media literacy, we will not become passive receivers in the future. It is also noteworthy that if our university graduates (especially those who are interested in teaching) fail to manage their negative emotions, sympathy and establish human and spiritual relationships based on emotional intelligence, it does not matter how much they are wise. Despite the importance of emotional intelligence as well as teachers' and authorities' perception of its significance, its level of utilization in the field of education is rather low, which obviously should be changed.

8. Malekipour, A., Malekipour, M. (2014). A Survey of the Standards of Information Literacy among the Teachers of Dehloran Town, 4(3), 1-9.

9. Mansorian, Y., Naeim Abadi, M. (2005). The Role of Library's Websites in Promoting the Information Literacy. Training the Users and Developing Information Literacy in the Libraries. The Information and Museums Centers. National Conference on the Information Literacy (Mashhad): Organization of Libraries, Museums and Documents Center of Astan Ghods Razavi.

10. Miller Miller. (2008). The Advantages of Cultural Diversity in Business. How Hiring a Culturally Diverse Workforce can Benefit Your Business. Retrieved from: http://www.suit101.comlworkplaceculture.htm.

11. Miyagamwala, G. (2015). Emotional Intelligence and Teacher Effectiveness- An Analysis. Bharat College of Commerce and Science, 4, 233-239. Badlapur. India.

12. Mousapour, N. (2003). Principles of Intermediary Education Planning. Mashhad: Beh Publications.

13. Nasiri, B. (2013). Teaching Media Literacy in Canada and Japan. Educational Innovations, 11(41), 137160.

14. Nami, K., Bazargan, A., Naderi, A. (2014). The Relationship between Using Information technology by the Faculty Members and their Teaching Quality. 
Quarterly of Research \& Planning in Higher Education, $71,1-18$.

15. Sarmadiseif, A. (2012). Research Methodology in Education Sciences. $2^{\text {nd }}$ ed. Tehran: Agah Publications.

16. Sepasgozar, M. (2001). A Theoretical Approach towards Media Literacy. Research \& Evaluation Quarterly, 12(44).
17. Shibata, K. (2003). An Analysis of Critical Approach towards Media Literacy. Comparative Study between Japan and Canada. Zohreh Bidokhti (trans.). Media Quarterly, 40.

18. Taghizadeh, A., Kia, A. (2015). NeedsAssessment of the Curriculum of Media Literacy in the Schools. Culture Studies-Relationships, 15(26), 80-103.

\author{
Нассім Шамораді Варнамхасті, \\ магістр кафедри педагогіки, \\ філіал Ісфахан (Хорасган), Ісламський університет Азад, м. Ісфахан, Іран, \\ Маріам Бараталі, \\ доцент, кафедра педагогіки, Ісламський університет Азад, Ісфахан, Іран
}

\title{
СПІВВІДНОШЕННЯ МІЖ ІНФОРМАЦЙНОЮ ГРАМОТНІСТЮ, ЕМОЦІЙНИМ ІНТЕЛЕКТОМ ТА ЯКІСТЮ ВИКЛАДАННЯ ВЧИТЕЛІВ СТАРШОЇ ШКОЛИ
}

Стаття присвячена визначенню співвідношення між інформаційною грамотністю, емоційним інтелектом та якістю викладання вчителів старшої школи. Інформаційна грамотність є надзвичайно важливим аспектом діяльності вчителя, адже самі по собі інформаційні технології не можуть призвести до покращання успішності учнів або набуття знань з усіх предметів, тому їх використання та опрацювання мають були цілеспрямованими. Наразі кожен викладач має опановувати знання щодо використання інформаційних технологій та вміти застосовувати їх на практиці. Окрім цього, професія вчителя цілком і повністю пов'язана з емоційною сферою. Вчителі впливають на розвиток соціо-емоційних якостей учнів та водночас самі піддаються емоційному впливові 3 боку дітей. Вміння контролювати свої почуття є обов'язковою складовою професійної компетентності вчителя. Розвиток емоційного інтелекту як спроможності розуміти та контролювати свої емоції та емоції інших людей значно допоможе у навчальному процесі та взаємодії вчителя з учнями, що, в свою чергу, позитивно впливає на успішність дітей. Особливо потрібен емоційний інтелект у непередбачуваних ситуаціях негативного характеру, коли час на реагування обмежений, а обставини вимагають швидкої адаптації та вирішення проблеми. Було проведено дослідження, в якому взяли участь 130 вчителів, які викладають у старшій школі регіону Зерріншехр, яких було обрано випадковим методом із 460 осіб. Для оцінювання якості викладання на кожного вчителя було взято по 3 учні, які мали заповнити запропоновані їм анкети. У дослідженні використовувалися такі методики, як «Опитувальник на визначення інформаційної грамотності» (Ашрафі-Різі, 2014), «Тест на визначення якості викладання» (Зафдаріан та Хосровпур, 2015, в авторській адаптації), а також «Тест на самовизначення емоційного інтелекту» (Шутте, 1998). За результатами експерименту було виявлено значний позитивний зв'язок між інформаційною грамотністю, емоційним інтелектом та якістю викладання вчителів. Крім того, було встановлено, що різниця між середніми балами, отриманими за основнми змінними дослідження (емоційний інтелект, інформаційна грамотність і якість викладання) з точки зору деяких характеристик (а саме: статі, напряму підготовки, рівня освіти і досвіду викладання) не є статистично значущою. Отже, за результатами дослідження можна зробити висновок, що для покращання якості викладання вчителів необхідно розвивати в них інформаційну грамотність (що включає в себе навчання та саморозвиток впродовж життя), а також емоційний інтелект (наприклад, за допомогою спеціальних тренінгів, організованих психолого-педагогічною службою закладу).

Ключові слова: інформаційна грамотність, якість викладання, вчителі, старша школа, емоційний інтелект.

Подано до редакиії 25.12.2016 